EDUKACJA MIĘDZYKULTUROWA

2015, nr 4

ISSN 2299-4106

SABINA JANIK

\title{
Aspiracje edukacyjne uczniów imigrantów
}

Streszczenie: Przedmiotem zainteresowania autorki są aspiracje edukacyjne uczniów imigrantów. Odwołując się do badań zagranicznych i częściowo własnych, zwraca uwagę na wysokie aspiracje edukacyjne tej kategorii uczniów generalnie wyższe w stosunku do uczniów autochtonów o tym samym statusie społeczno-ekonomicznym. Stwierdza brak zgodności wśród badaczy w kwestii wyjaśniania uwarunkowań specyfiki tych aspiracji. Modele interpretacji mieszczące się w obrębie P. Bourdieu i J. C. Passerona teorii reprodukcji, G. S. Beckera racjonalności, inwestycji i rentowności czy R. Boudona logiki mobilności społecznej powiązanej z percepcją efektywności szkolnej nie dostarczają w pełni zadowalających wyjaśnień tej specyfiki. W związku z tym istnieje potrzeba poszukiwania komplementarnych modeli interpretacji tego fenomenu. Stąd propozycja wykorzystania do tego celu koncepcji społeczeństwa merytokratycznego.

Słowa kluczowe: uczniowie imigranci, aspiracje edukacyjne, specyfika aspiracji, uwarunkowania, modele interpretacji

W literaturze zagranicznej aspiracje edukacyjno-zawodowe uczniów imigrantów są częstym i dość dobrze rozpoznanym przedmiotem badań, w Polsce natomiast znajdują się w fazie początkowej.

W badaniach prowadzonych za granicą zarówno w krajach europejskich, jak i pozaeuropejskich zwrócono uwagę na pewną prawidłowość, a mianowicie na fakt stosunkowo wysokich aspiracji edukacyjno-zawodowych uczniów pochodzenia imigranckiego - generalnie wyższych w stosunku do uczniów autochtonów o tym samym statusie społeczno-ekonomicznym. Jednak brak wśród badaczy zgodności w kwestii wyjaśniania uwarunkowań specyfiki tych aspiracji. Pojawia się więc potrzeba poszukiwania dalszych, komplementarnych interpretacji tego fenomenu. Taką próbę podjęto w tym artykule.

Oto wybrane przykłady wyników badań zagranicznych konstatujących występowanie zjawiska wysokich aspiracji edukacyjno-zawodowych uczniów imigrantów oraz prób (nie w pełni zadowalających) jego wyjaśnienia. 
W Kanadzie w 2000 roku przeprowadzono badania ankietowe, które objęły ponad 26 tys. uczniów, reprezentujących 346 tys. piętnastolatków ze wszystkich 10 prowincji $^{1}$. Celem badań było zdiagnozowanie różnic dotyczących aspiracji edukacyjnych uczniów imigrantów mniejszości „widocznych” (pierwszej i drugiej generacji) oraz uczniów urodzonych w Kanadzie nienależących do grup „widocznych” mniejszości. Uczniowie z „widocznych” mniejszości stanowili $12 \%$ wszystkich uczniów. Abstrahując od takich zmiennych jak płeć, struktura rodziny, region, język macierzysty, wielkość wspólnoty imigranckiej, uczniowie imigranci należący do „widocznych” mniejszości aspirowali częściej do podjęcia studiów wyższych niż ich rówieśnicy urodzeni w Kanadzie i nienależący do „widocznych” mniejszości. Na przykład $84 \%$ dziewcząt z tej pierwszej grupy, z drugiej zaś 63\% zamierzało podjąć studia uniwersyteckie, a proporcje te wśród chłopców wynosiły odpowiednio $75 \%$ i $51 \%$.

Różnice w poziomie aspiracji uniwersyteckich występowały we wszystkich regionach kraju: uczniowie imigranci mniejszości „widocznych” wszędzie przejawiali ambitniejsze aspiracje. Aspiracje te utrzymywały się na wyższym poziomie, mimo że dla blisko $2 / 3$ imigrantów językiem macierzystym nie był ani język angielski, ani francuski.

Badania wykazały, że młodzi Kanadyjczycy w wieku 15 lat mają wysokie aspiracje edukacyjne, lecz młodzież imigrancka należąca do „widocznych” mniejszości ma je w jeszcze większym stopniu. Zaobserwowano stały efekt wpływ statusu imigranta $\mathrm{z}$ „widocznych” mniejszości, nawet po uwzględnieniu różnych zmiennych społeczno-demograficznych i wyników szkolnych. Poza tym niższe wykształcenie rodziców, ich dochody, oceny szkolne wydają się w mniejszym stopniu „wygaszać” aspiracje edukacyjne imigrantów z „widocznych” mniejszości niż Kanadyjczyków nienależących do tych mniejszości.

Suárez-Orozco i Suárez-Orozco ${ }^{2}$ sugerują, że rodzice imigranci, ponieważ doznali rozczarowania na skutek dewaluacji w kraju przyjmującym ich dotychczasowego prestiżu, pragną zapewne narzucić swym dzieciom wysokie aspiracje edukacyjne. James ${ }^{3}$ zaś dowodzi, że rodzice czarnej młodzieży

1 H. Krahn, A. Taylor: Resilient teenagers: explaining the high educational aspirations of visible minority immigrant youth in Canada. PCERII Working Paper Series 2005 (nr WPO2-05).

2 C. Suárez-Orozco, M. Suárez-Orozco: Children of immigrants. Cambridge 2001, Harvard University Press, s. 105.

3 C. James: Getting there and staying there: black's employment experience. W: P. Anisef 
wpajają jej niejako przekonanie, że ludzie są nagradzani dzięki ciężkiej pracy i osobistemu wysiłkowi. Do podobnych wniosków dochodzi MacLeod ${ }^{4}$, na podstawie badań etnograficznych życia młodzieży ze środowisk zmarginalizowanych w USA, który przeciwstawia akceptacji przez grupę czarnej młodzieży dyskursu równości szans, zanegowanie i odrzucenie tej ideologii przez białą młodzież o podobnym statusie. Ten optymizm czarnej młodzieży przypisuje jej odczuciu, że uczestniczą w „zbiorowej trajektorii w górę” (a collectiv upward trajectory). Przypuszcza więc, że wysokie aspiracje młodzieży imigranckiej odzwierciedlają zaakceptowanie przez jej rodziców zdyskontowanej wartości kredencjałów na rynku pracy i przeświadczenie o tym, że warunkiem sukcesu ich dzieci jest wzmożony wysiłek. Niektórzy badacze ${ }^{5}$ sądzą, że sieci społeczne społeczności imigranckich mogą również odgrywać pewną rolę w kształtowaniu aspiracji, wzmacniając rodzicielskie wysiłki w przekazywaniu wartości, norm i oczekiwań wobec młodzieży. W kontekście rozważań na temat tożsamości i aspiracji młodzieży imigranckiej z widocznych mniejszości Suárez-Orozco i Suárez-Orozco ${ }^{6}$ wyrażają pogląd, że młodzi ludzie, którzy rozwijają "dwukulturowe kompetencje” (bicultural competencies) są najlepiej przygotowani do wykorzystania swoich możliwości, ponieważ mają silne poczucie własnej tożsamości etnicznej, lecz również rozwijają „hybrydową tożsamość i kulturową formację”, przekształcając „starą" kulturę etniczną i „nową" większościową w sposób twórczy. W podobnym kierunku zmierza Perron ${ }^{7}$, argumentując, że uczniowie imigranci im mocniej utożsamiają się z kulturą własnej grupy, tym częściej przejawiają otwartość wobec innych grup kulturowych i jest prawdopodobne, że będą artykułować uniwersyteckie aspiracje edukacyjne.

We Francji, jak wynika z raportu odwołującego się do krajowych badań podłużnych (uczniów w wieku 16-18 lat) przeprowadzonych przez tamtejsze

\& P. Axelrod (eds): Transitions: schooling and employment in Canada. Toronto 1993, Thompson, s. 3-20.

4 J. MacLeod: Ain't no makin'it: Leveled aspirations in a low-income neighbourhood. Boulder1987, Westview.

5 J. Li: Parental expectations of Chinese immigrants. A folk theory about children's school achievement. "Race, ethnicity and education" 2004, nr 7 (2), s. 171-190.

6 C. Suárez-Orozco, M. Suárez-Orozco: Children of immigrants. cyt. wyd., s. 118.

7 J. Perron: Ethnicity and educational aspirations of high school students. W: B. Galaway, J. Hudson (eds): Youth in transition: perspectives on research and policy. Toronto1997, Thompson, s. 127-134. 
Ministerstwo Edukacji (1989-1995; 1995-2002; 1997-2004) ${ }^{8}$, odnotowano podobne zjawisko - występowanie niezmiennie wysokich aspiracji edukacyjno-zawodowych zarówno u rodziców, jak i u uczniów imigrantów.

Osiągnięcia szkolne uczniów imigrantów, konstatuje raport, w większym stopniu są zależne od ich przynależności do środowisk społecznie zmarginalizowanych niż od faktu bycia imigrantem. Niższe osiągnięcia dzieci imigrantów są przede wszystkim wynikiem ich gorszego przygotowania do podjęcia nauki na progu szkoły podstawowej niż innych uczniów. O ile bycie dzieckiem imigranta ma nieznacznie negatywny efekt w szkole podstawowej, efekt ten staje się pozytywny w szkole średniej. Gdy rekrutują się ze środowisk o podobnych statusie co autochtoni, uczniowie z rodzin imigranckich częściej trafiają do sekcji ogólnych i technologicznych (niż zawodowych) oraz częściej uzyskują w tych sekcjach maturę niż inni uczniowie. Raport podkreśla, że wyjaśnienia tego zjawiska należy szukać głównie w postawach rodzicielskich: rodziny imigranckie różnią się tym od innych rodzin ze środowisk zmarginalizowanych, że mają znacznie bardziej ambitne oczekiwania edukacyjne, te zaś mogą wynikać z tego, że rodziny imigranckie pochodzą często z krajów o ograniczonej ofercie edukacyjnej, podczas gdy wśród rodzin francuskich ze środowisk zmarginalizowanych niepowodzenia szkolne mają często charakter międzypokoleniowy. Te bardziej ambitne aspiracje szkolne stają się atutem w momencie orientacji szkolnej w końcowej fazie nauki gimnazjalnej (w collège), podczas której w dużym stopniu uwzględnia się sugestie rodziców. Przy analogicznych osiągnięciach szkolnych ambicje imigrantów dotyczące kariery szkolnej ich dzieci są większe niż innych rodzin ze środowisk defaworyzowanych. Rada klasowa zaś rozpatruje adekwatność życzeń rodziców do osiągnięć ucznia i rzadkością jest, aby starała się je modyfikować, proponując bardziej prestiżowe ścieżki kształcenia.

Autorzy raportu wyjaśniają specyfikę aspiracji rodzin imigranckich następująco:

- w odróżnieniu od rodzin nieimigranckich niepowodzenia szkolne ich dzieci nie mają charakteru międzypokoleniowego, ponieważ wiele rodzin rekrutuje się z krajów o bardzo ograniczonej ofercie edukacyjnej,

- rodziny imigranckie mają silniejszą tendencję do posiadania wyższych aspiracji szkolnych, ponieważ w bardzo wielu przypadkach mobilność społeczna jest jednym z ważnych motywów ich imigracji,

8 Y. Brinbaum, A. Kieffer: D’une génération à l'autre: les aspirations éducatives des familles immigrés. Ambitions et pérséverance. "Education et formation" 2005, nr 72, s. 67 i n. 
- wyższe aspiracje szkolne rodzin imigranckich mogą też świadczyć o antycypacji trudności, jakie mogą napotkać ich dzieci na rynku pracy,

- dłuższy okres przebywania we Francji wydaje się wzmacniać przekonanie imigrantów o celowości wyboru licealnych sekcji ogólnych i technologicznych (a więc o większym prestiżu) oraz wiarę w profesjonalną użyteczność dyplomów szkolnictwa wyższego.

Z jednej strony - rodziny imigranckie należą do tych, które oczekują najwięcej od systemu edukacyjnego i artykułują najambitniejsze aspiracje edukacyjne, a z drugiej - należą w zdecydowanej większości do środowisk społecznych zmarginalizowanych, a ta przynależność sprawia, że w ramach systemu edukacyjnego, w którym powodzenie szkolne zależy w dużym stopniu od pochodzenia społecznego, dzieci z rodzin imigranckich są szczególnie narażone na niepowodzenia szkolne.

Rodzi to pytanie: jaki związek z planami życiowymi dzieci imigrantów ma ten rozziew między osiągnięciami szkolnymi i wysokimi aspiracjami ich rodziców? Czy konsekwencją nie jest spadek poziomu ambicji szkolnych i zawodowych dzieci imigrantów, czy też wiernie powielają wysokie aspiracje swych rodziców? Jak dowodzi ww. raport, dzieci imigrantów wiernie odtwarzają wysokie aspiracje swych rodziców oraz pragnienie zmiany na lepsze statusu społecznego, które często jest czynnikiem determinującym podjęcie decyzji migracyjnej. Dlatego właśnie aspirują one do podejmowania studiów na selekcyjnych kierunkach szkolnictwa wyższego krótkiego cyklu, aby pracować w dziedzinie handlu i administracji, które moga zapewnić im dostatnie życie. Tak więc, przy porównywalnych cechach społeczno-demograficznych uczniów, posiadanie rodziców imigrantów jest czynnikiem najsilniej oddziałującym na zamierzenia kontynuowania nauki. Mimo częstej reorientacji szkolnej, relegującej ich do sekcji zawodowych, większość tych uczniów (trzy czwarte) pragnie kontynuować naukę w szkolnictwie wyższym. Aspiracje szkolne uczniów imigrantów w odniesieniu do studiów wyższych są również wyższe, w sytuacji równych osiągnięć szkolnych, niż aspiracje np. młodych Francuzów. Porównanie aspiracji rodziców imigrantów z aspiracjami ich dzieci wykazało w tym zakresie określone prawidłowości.

Zjawisko to zostało potwierdzone w innych badaniach ${ }^{9}$. Ujawniły one preferowanie studiów licencjackich o kierunku technicznym przez uczniów Portugalczyków, a studiów uniwersyteckich ogólnych przez uczniów imigrantów

9 Y. Brinbaum, H. Cebolla-Boado: The school careers of ethnic minority youth in France. "Ethnicities" 2007, nr 7 (3). 
z Maghrebu oraz generalnie większe oczekiwania rodzin imigranckich względem osiągnięć szkolnych i zawodowych niż rodzin nieimigranckich.

Inni autorzy podejmujący tę problematykę we Francji wyrażają pogląd, że nie sposób zrozumieć wysokich aspiracji rodziców imigrantów, przekładających się na aspiracje uczniów imigrantów, mobilizacji rodzin imigranckich na płaszczyźnie edukacyjnej, nie uwzględniając stosunków społecznych i szkolnych; wskazują, że tę mobilizację należy postrzegać jako przejaw strategii defensywnej i kompensacyjnej, realizowanej przez imigrantów w społecznym kontekście dyskryminacji: dyskryminacji etnicznej na rynku pracy, często ukrytej, generującej determinację edukacyjną imigrantów ${ }^{10}$.

W Wielkiej Brytanii w latach 60. i 70. XX wieku badacze koncentrowali swoje zainteresowania na kontekstach rodzinnych, w których wychowywały się dzieci mniejszości. Często wskazywali na negatywne cechy struktur rodzinnych i modeli wychowawczych mniejszości, zwłaszcza mniejszości afro-antylskiej ${ }^{11}$. Jednak w tym samym czasie pozytywna rola oddziaływania imigranckiego środowiska rodzinnego na przebieg nauki szkolnej dzieci nie uszła uwadze badaczy, którzy odeszli od orientacji eksponującej deficyty rodzinnego środowiska. I tak bardziej pozytywny ogląd roli rodziny pojawił się u badaczy, którzy analizowali aspiracje i oczekiwania rodzin. Większość z nich wskazywała i podkreślała, że rodzice imigranci mają wobec swych dzieci oczekiwania edukacyjne, których poziom ambicji jest porównywalny, a nawet wyższy niż u rodziców pochodzenia anglosaskiego, że interesują się też bardzo postępami w nauce swego potomstwa. Rodzice Azjaci w większym stopniu niż pozostali imigranci starali się oddziaływać na wybory dróg kształcenia swych dzieci ${ }^{12}$.

10 J.-P. Zirotti, R. Akers-Porrini: Élèves "français" et "maghrébins". Un rapport different à l'orientation scolaire. "Migration-Formation" 1992, nr 89, s. 45-57; M. Tribalat: Faire France. Une enquête sur les immigrés et leurs enfants. Paris 1995, La Découverte.

11 M. Rutter et al.: Children of West Indian immigrants. Rates of behavioral deviance and psychiatric disorder. "Journal of Child Psychology and Psychiatry" 1974, nr 15, s. 241-262.

12 B. Coard: Haw the West Indian child is made educationally sub-normal in the British school system. London 1971, New Beacon Books; R. Collins: The credential society. An historical sociology of education and signification, New York 1979, Academic Press; Y. P. Gupta: The educational and vocational aspirations of Asian immigrant and English school-leavers - a comparative study. "British Journal of Sociology" 1977, $\mathrm{nr} 28$; J. Rex, S. Tomlinson: Colonial immigrants in a British city-a class analysis. London 1979, Routlege \& Kegan Paul. 
W Stanach Zjednoczonych Ogbu wskazywał, że czarni uczniowie, mimo oporu, jaki wykazują wobec szkolnej nauki, zdają się mieć wyższe aspiracje niż ich biali rówieśnicy. Argumentował, że tożsamość szkolna tych pierwszych kształtuje się głównie na bazie historycznego doświadczenia oporu wobec dyskryminacyjnego traktowania ze strony społeczeństwa dominującego, doświadczenia przekazywanego w środowisku rodzinnym i wspólnotowym ${ }^{13}$.

Badania, które przeprowadziłam $\mathrm{w}$ ramach pracy doktorskiej ${ }^{14} \mathrm{w}$ roku szkolnym 2010/2011 w publicznych i niepublicznych gimnazjach i liceach aglomeracji warszawskiej (na próbie 284 uczniów cudzoziemskich z UE/EFTA i krajów Trzeciego Świata ${ }^{15}$ ), pokazują, że większość uczniów cudzoziemskich charakteryzuje się przeciętnymi lub podwyższonymi aspiracjami edukacyjno-zawodowymi (biorąc pod uwagę teoretyczną dyspersję wyników).

Młodzież cudzoziemska ma świadomość wartości wykształcenia. W większości uczniowie imigranci z badanej próby chcą osiągnąć wykształcenie przynajmniej na poziomie licencjackim lub inżynierskim. Aż jedna trzecia osób (32\%; $\mathrm{N}=87$ ) chciałaby podjąć specjalistyczne kształcenie podyplomowe. Najczęściej badani wskazywali na następujące typy uczelni: ekonomiczne $(19,6 ; \mathrm{N}=54)$, humanistyczne $(16,7 \% ; \mathrm{N}=46)$, techniczne $(13,5 \% ; \mathrm{N}=37)$, a w dalszej kolejności - medyczne, artystyczne i inne.

Wykształcenie niższe niż średnie nie satysfakcjonuje żadnego z badanych uczniów, a szkołę średnią lub pomaturalną chciałoby ukończyć tylko 8,8\% $(\mathrm{N}=24)$ badanych. Zarówno w gimnazjum, jak i liceum młodzież ta ma już sprecyzowane dążenia edukacyjne - jedynie 20,7\% uczniów jeszcze nie zdecydowało się na dalszy kierunek kształcenia.

13 W. Rabczuk: Niepowodzenia szkolne dzieci imigrantów w świetle badań amerykańskich i francuskich. W: T Lewowicki, E. Ogrodzka-Mazur (red.): W poszukiwaniu teorii przydatnych $w$ badaniach międzykulturowych. Cieszyn 2001, UŚ - Filia w Cieszynie, s. 32 i n.

14 S. Janik: Aspiracje i plany edukacyjno-zawodowe uczniów cudzoziemskich $w$ aglomeracji warszawskiej. Praca doktorska napisana pod kierunkiem naukowym prof. zw. dr. hab. W. Rabczuka. Warszawa 2012.

15 Za kraje Trzeciego Świata uznaje się kraje nienależące do Unii Europejskiej i Europejskiego Stowarzyszenia Wolnego Handlu ( EFTA). EFTA - organizacja międzynarodowa powstała w 1960 r. Jej głównym zadaniem jest zniesienie ograniczeń ilościowych i celnych oraz innych przeszkód we wzajemnym handlu opartym na wolnej konkurencji. W skład EFTA wchodzą obecnie Islandia, Lichtenstein, Norwegia i Szwajcaria. 
Preferowany obszar zawodowy uczniów imigrantów to zawody związane z branżą ekonomiczną $(18,7 \% \mathrm{~N}=39)$, artystyczną $(13,4 \% ; \mathrm{N}=28)$, medyczną $12,4 \% ; \mathrm{N}=26$ ), a na kolejnych pozycjach znalazły się prawna, inżynieryjna, sportowa, informatyczna oraz badawczo-rozwojowa. Jeśli chodzi o poziom wykształcenia umożliwiający realizację planów zawodowych, to jedynie $12,9 \%$ badanych uczniów imigrantów podało zawód wymagający wykształcenia średniego, a $24 \%$ zawód wymagający wykształcenia licencjackiego/inżynierskiego. Pozostali preferowali zawody wymagające minimum wykształcenia na poziomie magisterskim. Najczęściej wskazywanym powodem wyboru zawodu była jego zgodność z zainteresowaniami i szansą rozwoju (58,6\%; $\mathrm{N}=147$ ), możliwość zarobienia dużych pieniędzy $17,9 \%$; $\mathrm{N}=45$ ), a zawody cenione społecznie i prestiżowe uzyskały najmniej wskazań $(9,2 \% ; \mathrm{N}=23)$. Preferowane miejsca pracy to własna firma lub firma prywatna, natomiast państwowy zakład pracy wskazało tylko 5,2\% uczniów. Blisko jedna czwarta respondentów nie wiedziała jeszcze, jakie mogłaby wybrać przyszłe miejsce pracy.

Ponadto ważnym czynnikiem jest status prawny ucznia cudzoziemskiego. Generalnie poziom aspiracji edukacyjno-zawodowych jest wyższy u uczniów imigrantów niż uczniów uchodźców i obywateli UE. Przy czym uchodźcy charakteryzują się najniższym poziomem aspiracji edukacyjno-zawodowych.

W zakresie przeciętnego poziomu aspiracji edukacyjno-zawodowych różnica wystąpiła przy rozpatrywaniu odpowiedzi uczniów pochodzenia nieazjatyckiego i azjatyckiego. Wartość wykształcenia i wiedzy wydaje się ważniejsza dla uczniów pochodzenia azjatyckiego $(M=4,35)$ niż dla uczniów pochodzenia nieazjatyckiego $M=4,97$ ).

Rodzice z krajów UE/FTA i krajów Trzeciego Świata nie różnią się zasadniczo w postrzeganiu roli edukacji i planów zawodowych: czują się odpowiedzialni za edukację i przyszłość zawodową swoich dzieci. Najczęściej jako pożądany poziom wykształcenia wskazywali studia wyższe oraz praktyczny charakter zawodów dla swoich dzieci. Rola motywacji zewnętrznej jest więc stosunkowo duża oraz ujawnia istotny efekt transgeneracyjnego przekazu wartości, który występuje najsilniej w grupie rodziców pochodzących z krajów azjatyckich i innych krajów Trzeciego Świata. Należy zaznaczyć, że wśród badaczy zagranicznych występuje konsensus co do czynników sprawczych sukcesów szkolnych i wysokich aspiracji studentów i uczniów imigrantów pochodzenia azjatyckiego: upatruje się je przede wszystkim w specyfice kulturowej tej grupy imigrantów. 
Badania $\mathrm{Yu}^{16}$ wskazują, że Chińczycy cechują się ogólnie większym natężeniem motywacji osiągnięć niż populacja nieazjatycka, co wynika z chińskiej orientacji kolektywistycznej. Silną motywację osiągnięć jako rudymentarną wartość w społeczeństwach kolektywistycznych podkreślają również Harrison i Huntington. Ma i Yeh ${ }^{17}$ badali, jak cechy indywidualne i czynniki rodzinne oddziałują na aspiracje i plany edukacyjne i zawodowe chińskiej młodzieży (265 uczniów) uczącej się w nowojorskich liceach. Badania potwierdzają, że aspiracje tej młodzieży (ujawnione w badanej próbie uczniów) są pośredniczone m.in. przez wysokie aspiracje edukacyjne rodziców i wsparcie, jakie oferują swoim dzieciom. Analiza aspiracji dzieci chińskich imigrantów w Kanadzie prowadzi do podobnych wniosków ${ }^{18}$ : rodzice starają się przekazać dzieciom wartości wypływające z chińskiej tradycji. Imigranci chińscy stawiają sobie za cel wykształcenie dzieci oraz ich integrację z nowym środowiskiem społecznym. Działania te służą m.in. stworzeniu perspektyw rozwoju zawodowego dla dzieci i polepszeniu statusu socjoekonomicznego całej rodziny.

W 2010 roku ukazała się w Stanach Zjednoczonych książka Amy Chua, urodzonej w USA Chinki, Battle Hymne of the Tiger Mother (Hymn bojowy matki-tygrysicy) ${ }^{19}$. Książka (przełożona na wiele języków, w tym język polski) zyskała rozgłos i stała się przedmiotem ożywionych dyskusji na temat uwarunkowań sukcesów edukacyjnych. Chua ocenia model wychowawczy Zachodu jako wywodzący się z permisywnej tradycji i przeciwstawia go chińskiemu modelowi opartemu na autorytecie rodziców i nauczycieli.

W 2009 roku w Chinach i na Tajwanie wyjątkową popularnością cieszyła się piosenka zatytułowana Stuchaj słów mamy, wykonywana przez młodego Tajwańczyka, idola nastolatek. Jej przesłanie jest skierowane do młodzieży: należy pilnie się uczyć, a nagrodą za wyrzeczenia będzie jutrzejszy sukces. W tej części świata od czasów Konfucjusza rodziców słucha się i darzy szacunkiem. Od pilnowania postępów w nauce jest mama. Edukacyjna mama mówią Japończycy. „Pięć za dużo, cztery w sam raz” - tyle godzin wolno

16 E. S. Yu: Chinese collective orientation and need for achievement. "International Journal of Social Psychiatry" 1980, nr 26 (3), s. 184-189.

17 P. W. Ma, Ch. J. Yeh: Individual and familial factors influencing the educational and career plans of Chinese immigrant youths. "Career Development Quarterly" 2010, nr 58 (3), s. 230-245.

18 J. Li: Parental expectations of Chinese immigrants: a folk theory about children's school achievement. cyt. wyd.

19 A. Chua: Bojowa pieśń tygrysicy. Warszawa 2011, Prószyński Media. 
spać koreańskim uczniom, jeśli chcą zdać egzamin maturalny z odpowiednią liczbą punktów umożliwiającą dostęp do prestiżowych uczelni ${ }^{20}$.

Tradycyjnie socjalizacyjna funkcja szkolnictwa w Korei Południowej polega w znacznym stopniu na dyscyplinie moralnej, szacunku dla pracy i podejmowania wysiłku kształcenia. Takie podejście ma swoje źródło w tradycji konfucjanizmu, który eksponuje wartość edukacji i norm moralnych. Koreańscy uczniowie charakteryzują się wysoką motywacją napędzaną niezwykle intensywną rodzicielską presją sukcesu ${ }^{21}$.

Książka Amy Chua, jak i piosenkarski hit Ting ma ma de hua ułatwiają dostrzeżenie (niektórych) uwarunkowań aspiracji i sukcesów edukacyjnych dzieci imigrantów chińskich i koreańskich.

Sinolog i orientalistka T. Halik, analizując sytuację dzieci wietnamskich w polskiej szkole, podkreśla, że kultura wietnamska wyniosła z konfucjanizmu szacunek dla dobrze wykształconych: „Wykształcenie było bowiem traktowane jako podstawowy środek poruszania się w górę drabiny społecznej. Oznaczało ono uzyskanie wysokiego statusu społecznego, co miało swoje przełożenie na podwyższenie statusu własnego rodu"22. Konfucjanizm nakładał na rodziców obowiązek zapewnienia dzieciom jak najlepszej przyszłości, albowiem posiadanie dzieci oznaczało zachowanie ciągłości linii rodowej, kontynuację tradycji rodzinnych. Zdaniem Halik badania potwierdzają, że nadal oczekuje się takiego postępowania od wietnamskich rodziców.

Wyjaśnienia fenomenu sukcesów Wietnamczyków należy także upatrywać, jak stwierdza Halik, w kompatybilności wartości dwóch kultur, nawet jeśli kultury te wydają się odległe od siebie. Dziecko wietnamskie dzięki socjalizacji pierwotnej zdobyło umiejętności, które nie stoją w sprzeczności z umiejętnościami, jakich oczekuje od dziecka polski system szkolny, jest bowiem postrzegane jako zdyscyplinowane, inteligentne i pracowite, a jego sukces edukacyjny w polskiej szkole jest ważną wartością zarówno w kulturze wietnamskiej, jak i polskiejej.

Wydaje się, że występujący w Polsce stereotyp Wietnamczyka - handlarza i kucharza w niedługim czasie przestanie funkcjonować. Wietnamskie dzieci

20 M. Kruczkowska: Azjatyckie supermatki. „Gazeta Wyborcza” 2012, nr 4.04, s. 17.

21 A. Gromkowska-Melosik, T. Gmerek: Problemy nierówności społecznej w teorii i praktyce edukacyjnej. Kraków 2008, Oficyna Wydawnicza „Impuls”, s. 165, 181.

22 T. Halik, E. Nowicka, W. Połeć: Dziecko wietnamskie w polskiej szkole. Warszawa 2006, Wydawnictwo „Prolog”, s. 108.

23 Tamże, s. 180, 195-196. 
uczące się w Warszawie chcą zostać prawnikami, artystami, politykami. Często biorą udział w olimpiadach naukowych, znają po kilka języków obcych i mają ambitne plany na przyszłość. W ocenie nauczycieli i dyrekcji szkół jest to bezproblemowa i bardzo dobrze ucząca się młodzież. W swym reportażu o wietnamskich dzieciach, które są prymusami w warszawskich szkołach, M. Zieliński ${ }^{24}$ podaje kilka konkretnych przykładów świadczących zarówno o bardzo dobrych wynikach w nauce, jak i wielkich planach na przyszłość wietnamskich uczniów. Taką uczennicą jest Thu Ha Do Van, 13-latka, której średnia ocen $\mathrm{w}$ gimnazjum to 5,0. Mówi w pięciu językach: po polsku, angielsku, wietnamsku, rosyjsku i francusku. Wygrała olimpiadę szkolną z matematyki, jej prace z języka polskiego i historii szkoła wysłała na ogólnopolskie konkursy. Jej dobre wyniki w nauce wzbudzają często wśród rówieśników niezdrowe emocje, lecz takie sytuacje motywują ją do jeszcze większego wysiłku. „Wiem, że jak będę się dobrze uczyć, to dostanę się na studia prawnicze. Gdy je skończę, chcę zostać burmistrzem, potem ministrem spraw zagranicznych, a na zakończenie mojej kariery będę pierwszą kobietą prezydentem Polski. Wtedy pokażę tym wszystkim, którzy mi dokuczali" - dodaje z przekorą.

Wietnamczykom bardzo zależy na tym, żeby dzieci dobrze się uczyły. Rząd Wietnamu i organizacje wietnamskie wspierają je w tym dążeniu. Stowarzyszenie Kobiet Wietnamskich w Polsce co jakiś czas zbiera pieniądze wśród rodaków i za nie kupuje dobrym uczniom prezenty. Ambasada Wietnamska funduje co roku dla najlepszych uczniów wakacje w Wietnamie.

Wietnamczycy, Koreańczycy i Chińczycy nie stanowią wyjątku wśród populacji azjatyckiej. Jak dowodzi M. Cylkowska-Nowak, „Dzieci i młodzież w Japonii poddawane są socjalizacji, której zasadniczym celem jest „podgrzewanie” ich ambicji edukacyjnych i wyposażenie w cechy psychiczne, które umożliwią osiągnięcie sukcesu"25. To matka ponosi pełną odpowiedzialność za ukształtowanie u dziecka podstawowych umiejętności społecznych, na które składają się podporządkowanie grupie, samodyscyplina, pracowitość i wytrwałość.

Jednak wyjaśnień czynnikami kulturowymi źródeł sukcesów edukacyjnych azjatyckich uczniów i ich wysokich aspiracji nie sposób odnosić do wszystkich grup etnicznych uczniów imigrantów.

24 M. Zieliński: Zostanę prezydentem Polski. „Gazeta Wyborcza. Stołeczna” 2005, nr 8-9.10, s. 2.

25 M. Cylkowska-Nowak: Społeczne funkcje szkolnictwa w Japonii i Stanach Zjednoczonych (stadium z pedagogiki porównawczej). Poznań - Toruń 2000, „Edytor”, s. 198. 
Czy nie należy więc poszukiwać dodatkowych wyjaśnień w teoriach społecznych nierówności?

Nierówności społeczne w dostępie do kształcenia, a zwłaszcza do wyższych i najwyższych szczebli szkolnictwa, utrzymują się nadal. Te nierówności konstytuują, oprócz nierówności społecznych osiągnięć szkolnych, nierówności w wyborach dróg kształcenia, pojawiające się począwszy od najniższych szczebli nauczania. Nierówności w wyborach mają tendencję do kumulowania się na każdym kolejnym progu kształcenia. W związku z tym nierówności w wyborach szkolnych lub aspiracje edukacyjne (rozumiane jako wybory szkolnych karier i plany na przyszłość uczniów w systemie szkolnym) wyjaśniają dużą część nierówności w przebiegu karier edukacyjnych.

Wobec tego rodzaju ustaleń, zapoczątkowanych w latach 60. XX wieku, ekonomiści i socjologowie edukacji zajęli się problematyką źródeł wyborów dróg kształcenia (aspiracji) szkolnych, tworząc różne modele. Dominująca w socjologii perspektywa deterministyczna ustępuje współcześnie w dużym stopniu podejściu, które na wzór ekonomistów akcentuje rolę jednostki i jej strategii.

Prace socjologów dotyczące aspiracji, zwłaszcza we Francji, sytuują się $\mathrm{w}$ ramach socjologii edukacji, przede wszystkim w ramach modeli autorstwa P. Bourdieu i R. Boudona. Ich modele reprezentują dwa przeciwstawne nurty socjologii: holizm (pogląd, zgodnie z którym struktury zachowują pierwszeństwo w stosunku do jednostki) i indywidualizm (pogląd, który koncentruje się na aktywnym homo sociologicus).

Te modele teoretyczne ukazują raczej ich potencjał i komplementarność, niż różnice, lecz również ich pewną nieadekwatność w kontekście niektórych empirycznych ustaleń, zwłaszcza w odniesieniu do imigrantów.

W obrębie teorii reprodukcji Bourdieu i Passeron, starając się wyjaśnić zróżnicowany przebieg karier/wyborów szkolnych czy wręcz izolowanie w szkole quasi-systemowe dzieci ze środowisk ludowych, dokonują interpretacji nierówności aspiracji szkolnych i zawodowych. I tak, Bourdieu nierówności społeczne osiągnięć szkolnych wyjaśnia „dziedzictwem kulturowym”, które jest różne w różnych klasach społecznych. Sprzyja ono w mniejszym lub większym stopniu osiągnięciom szkolnym, jest bowiem mniej lub bardziej zbliżone do szkolnych norm doskonałości ${ }^{26}$. Szkoła „obojętna na różnice" jednakowo traktuje niejednakowych uczniów, skazując część z nich na

26 P. Bourdieu, J.-C. Passeron: Les héritiers: les étudiants et la culture. Paris 1964, Editions de Minuit. 
niepowodzenia. Lecz nierówności w osiągnięciach szkolnych są generowane również przez mechanizmy związane z „dyspozycjami”, stosunkiem jednostek do szkoły, albowiem habitus (system wartości wewnętrznych, narzuconych i głęboko zinterioryzowanych w wyniku socjalizacji rodzinnej w społecznym środowisku pochodzenia), dziedziczony w równym stopniu jak kapitał kulturowy, dyktuje jednostkom w sposób nieuświadomiony ich działania, warunkując ich upodobania, preferencje, wartości i wyobrażenia dotyczące przyszłości. Habitus jest oczywiście ustrukturyzowany społecznie, a kultura społeczna odniesienia via habitus oddziałuje na preferencje, a więc i na aspiracje edukacyjne rodzin i uczniów, ich wyobrażenia o szkole oraz plany na przyszłość. Postawy członków różnych klas społecznych, rodziców i dzieci, a zwłaszcza postawy wobec szkoły, kultury szkolnej oraz przyszłości proponowanej przez szkołę w znacznym stopniu odzwierciedlają systemy wartości jawnych lub ukrytych, które są związane z ich przynależnością społeczną ${ }^{27}$. Bourdieu poddaje krytyce socjologów „[...] skłonnych do traktowania dyspozycji i predyspozycji wobec szkoły, czyli »nadziei«, »aspiracji«, »motywacji«, »woli« itp. w oderwaniu od społecznych warunków ich wytwarzania. Zapominając, że obiektywne warunki określają równocześnie aspiracje i stopień, w jakim mogą być one spełnione, pozwalają sobie skarżyć się na ten najlepszy ze światów, gdy w wyniku długotrwałego badania karier szkolnych odkrywają, że - jakby za sprawą wcześniej ustalonej harmonii - jednostki nie marzyły o niczym, czego już wcześniej nie uzyskały i nie uzyskały tego, o czym nie marzyły"28.

Ta koncepcja Bourdieu i Passerona socjalizacji pierwotnej o trwałym charakterze zdaje się zakładać pewien determinizm: jednostka jawi się jako przedmiot pasywny, którego zachowanie jest efektem przyczyn społecznych. Podobnie, wciąż via habitus, bardziej niż kształtowanie preferencji strukturyzowanych przez kulturę klasową, aspiracje szkolne i plany na przyszłość miałyby również stanowić interioryzację obiektywnej rzeczywistości, a więc istniejących możliwości, ponieważ aspiracje i wymagania są definiowane zarówno co do formy, jak i treści przez obiektywne warunki, które wykluczają (eliminują) niemożliwość (niewykonalność). „W zależności od tego, czy dostęp do wyższego wykształcenia jest zbiorowo odczuwany, nawet w mglisty sposób, jako perspektywa niemożliwa, możliwa, prawdopodobna bądź banal-

27 P. Bourdieu: L'école conservatrice. Les inégalités devant l'école et devant la culture. "Revue française de sociologie"1966, vol. 2, nr 3, s. 330.

28 P. Bourdieu, J.-C. Passeron: Reprodukcja. Elementy teorii systemu nauczania. Warszawa 2011, PWN, s. 323. 
na, zmienia się całe postępowanie rodzin i dzieci (a zwłaszcza ich zachowania i osiągnięcia szkolne), ponieważ usiłuje ono dopasować się do tego, czego można się »rozsądnie« spodziewać. W tej mierze, w jakiej ilościowo różnym poziomom szans zbiorowych odpowiadają jakościowo różne doświadczenia, obiektywne szanse określonej kategorii społecznej stanowią (za pośrednictwem obiektywnego przeznaczenia kategorii) jeden z mechanizmów, dzięki któremu urzeczywistnia się owo obiektywne przeznaczenie"29.

Wszystko dzieje się tak, jak gdyby intuicyjnie uczniowie i ich rodziny dostosowywały swoje oczekiwania do tego, na co pozwala im ich kondycja lub klasa społeczna. Ta idea ukrytej interioryzacji możliwości (tego, co możliwe) stanowi drugi mechanizm, który przyczynia się do nierówności w przebiegu kariery szkolnej, albowiem konstytuuje, poza preferencjami kulturowymi, zróżnicowane aspiracje, aspiracje, które w momencie orientacji szkolnej nakładają się na nierówności osiągnięć. Tak więc u Bourdieu socjalizacja, habitus i wyobrażenia społeczne są procesami kształtującymi zróżnicowane działania, w tym również aspiracje.

Zupełnie inną perspektywę przyjmują ekonomiści, albowiem mają tendencję do postrzegania zachowania człowieka w sposób ogólny, uniwersalny (podobnie jak psychologowie) oraz wykraczający poza grupy społeczne: starają się zdefiniować logikę działania wspólną dla wszystkich jednostek, niezależnie od ich przynależności klasowej i płciowej, opartą na racjonalności, inwestycji i rentowności, a więc kierującą się zasadą użyteczności. Ekonomiści edukacji mają tendencję wyjaśniania logiki wyborów indywidualnych i aspiracji edukacyjnych postępowaniem racjonalnym i wspólnym dla wszystkich, zorientowanym przede wszystkim na rentowność monetarną kapitału ludzkiego, w który się inwestuje ${ }^{30}$. W ten sposób uczniowie i ich rodziny są podmiotami ekonomicznymi - konsumentami szkoły i kształcenia. Ich zapotrzebowanie na edukację - ponieważ związane jest z kosztami - powinno być, według zasady każdej inwestycji, rentowne. Decydując się na określony rodzaj kształcenia, mają nadzieję na dostęp do pracy lepiej wynagradzanej $\mathrm{z}$ uwagi na kompetencje lub kapitał ludzki, zdobywany m.in. w czasie nauki. Dlatego też przed dokonaniem wyboru w momencie orientacji szkolnej szacują koszty kształcenia oraz czas jego trwania. Następnie zestawiają te koszty

29 Tamże, s. 333.

30 G. S. Becker: Human capital: a theoretical and empirical analysis, with special reference to education. Chicago1964, University of Chicago Press (kilkakrotnie wznawiane). 
z przewidywanymi korzyściami związanymi z kształceniem, uznając planowaną inwestycję jako rentowną lub nierentowną. Podmioty ekonomiczne konsumenci edukacji dokonują więc wyborów w sposób racjonalny, biorąc pod uwagę wyłącznie rentowność. Według Beckera edukację kontynuuje się tak długo, jak uznaje się ją za rentowną.

Boudon, nawiązując do ekonomicznego modelu interpretacyjnego oraz uznając istnienie nierówności społecznych, z jednej strony - podważa tezę ekonomicznego modelu działania logicznego, zakładającego wcześniejsze istnienie preferencji właściwych jednostce, a z drugiej - podkreśla istotną rolę podmiotów działających w obrębie określonego systemu (choć nie odrzuca zasadności badań struktur społecznych). We Wprowadzeniu do swego dzieła Efekt odwrócenia z 1993 roku, nie negując potrzeby poświęcania uwagi strukturom, stwierdzał: „nie można wyjaśnić w sposób zadowalający zjawisk społecznych będących przedmiotem zainteresowania socjologa, jeśli się ich nie uzna za skutki działań indywidualnych" ${ }^{31}$. Boudon odrzuca wyjaśnienie nierówności edukacyjnych poprzez odwoływanie się do kapitału kulturowego i jego nierównego rozdysponowania. Rozpatruje nierówności jako rezultat indywidualnych strategii, motywowanych własnymi potrzebami, wpływem otoczenia oraz kalkulacją ewentualnego ryzyka, a nie siłą oddziaływania zewnętrznych struktur.

W ujęciu Boudona zróżnicowane społecznie aspiracje nie są rezultatem niższych aspiracji osób ze środowisk „wrażliwych społecznie”, lecz rezultatem aspiracji odniesionych do pozycji na drabinie społecznej. Na wzór ekonomistów Boudon traktuje aktora jako podmiot wyposażony w racjonalność, która jest źródłem wyborów. Zaobserwowane społeczne prawidłowości nie są pochodną niższych ambicji edukacyjnych w grupach społecznie zmarginalizowanych na skutek niedoceniania przez nie edukacji oraz interioryzacji możliwości (tego, co możliwe), lecz wynikiem agregacji zachowań jednostek, których ambicję należy mierzyć odpowiednio do pozycji społecznej. Dziecko robotnika nie będzie miało potrzeby kształcenia się $\mathrm{w}$ długim i zbyt prestiżowym cyklu, aby kończąc swoją solaryzację osiągnąć pozycję społeczną wyższą od swoich rodziców. Osoba pochodząca ze środowiska defaworyzowanego, która osiągnęła pewien poziom wykształcenia, oceniany przez nią jako relatywnie wysoki w odniesieniu do swojego najbliższego otoczenia, może odczuwać zahamowania przed kontynuowaniem edukacji w związku z koniecznością wejścia na

31 R. Boudon: Efekt odwrócenia. Niezamierzone skutki działań społecznych. Warszawa 2008, Oficyna Naukowa, s. 7. 
rynek pracy i zdobycia samodzielności finansowej oraz przewidywanym ryzykiem, jeśli nie uczyni tego możliwie szybko. Tymczasem osoba wywodząca się z uprzywilejowanych warstw społecznych (np. syn lekarza) może odczuwać potrzebę wyższego wykształcenia, aby osiągnąć pozycję społeczną co najmniej równorzędną z pozycją rodziców, nie musi też kalkulować ewentualnego ryzyka finansowego. W tej koncepcji pozycja społeczna racjonalnego podmiotu oddziałuje na wszystkie parametry decyzji edukacyjnych - decyzji, które w zasadzie u Boudona dotyczą wyborów wertykalnych: kontynuować lub nie kontynuować nauki. Tak więc te parametry, na podobieństwo inwestycji edukacyjnych opisywanych przez ekonomistów, to efektywność (lub użyteczność), koszty i ryzyko związane z kontynuowaniem nauki. Specyfika tego modelu polega na powiązaniu logiki mobilności społecznej z percepcją efektywności inwestycji szkolnej. Należy odnotować, że Boudon w Logice działania społecznego swoją teorię wyboru edukacyjnego uzupełnił o hipotezę istnienia podkultur klasowych oraz o hipotezę deficytu kognitywnego. Przyjął „że jednym z odpowiedzialnych mechanizmów za KNW (klasowa nierówność w dostępie do wykształcenia) jest to, co można nazwać p o d k u l t u r a m i klas: fakt, że w klasach niższych częściej znajdujemy fatalistyczną i ekonomiczną koncepcję sukcesu powoduje, że owe klasy przeciętnie przypisują »studiom « mniejszą wartość” oraz za Bersteinem, Bourdieu i Passeronem „że niższe klasowo środowisko rodzinne rzadziej oferuje dziecku okazję do nauki technik złożonego wysławiania się, niż ma to miejsce w środowisku klas lepiej sytuowanych"32.

Niemniej istota jego mikrosocjologicznej teorii pozostała bez zmian, bowiem hipoteza o rachunku kosztów-korzyści zajmuje w niej centralne miejsce: „Przy tych samych okolicznościach, jednostka pochodząca z niższej klasy społecznej przeciętnie będzie wykazywała tendencję do niedoceniania przyszłych korzyści płynących z edukacyjnej inwestycji, [...] do przeceniania obecnych kosztów wiązanych z inwestycją edukacyjną, [...] do przeceniania ryzyka związanego z edukacyjną inwestycją" 33 .

Wydaje się, że żaden z tych modeli nie dostarcza w pełni satysfakcjonującego wyjaśnienia specyfiki aspiracji edukacyjnych uczniów imigrantów i autochtonów mających jednakowy status społeczny, tj. faktu, że aspiracje uczniów imigrantów sytuują się na zdecydowanie wyższym poziomie. Nie wyjaśnia też całkowicie zróżnicowania aspiracji edukacyjnych występujących

32 R. Boudon: Logika dziatania społecznego. Wstęp do analizy socjologicznej. Kraków 2009, „Nomos”, s. 126.

33 Tamże, s. 131. 
u różnych etnicznie grup (wspólnot) imigranckich. Te ustalenia skłaniają do relatywizowania znaczenia struktury społecznej, jak również „racjonalności”, a jednocześnie do ich uwzględniania.

Na przykład we Francji rodziny imigranckie pochodzące z krajów Maghrebu mają wyższe aspiracje niż rodziny francuskie o tym samym statusie społecznym. W kategorii robotników stwierdzono znaczące różnice między Portugalczykami, Francuzami i imigrantami z Maghrebu. Otóż, skoro aspiracje tych ostatnich są wyższe, podważa to zarówno „interioryzację możliwości” via habitus klasowy, jak i racjonalność rodzin, albowiem ich dzieci częściej doświadczają niepowodzeń szkolnych. Ze względu na pochodzenie robotnicze mają więc mniejsze szanse na sukces w profilach (sekcjach) ogólnych liceum i w szkolnictwie wyższym. Jednocześnie znalezienie pracy przez młodych imigrantów pochodzących z Maghrebu jest trudniejsze, mimo posiadania równorzędnych kwalifikacji. Jeśli dodamy do tego skromne środki materialne (dochody), jakimi dysponują te rodziny, biorąc pod uwagę posiadanie zazwyczaj większej liczby dzieci, zasadne staje się stwierdzenie, że aspiracje te nie są "racjonalne” ani zgodnie z ujęciem Beckera, ani z ujęciem Boudona. „Ambicje dzieci pochodzenia francuskiego wydają się bardziej realistyczne, niż dzieci pochodzenia imigranckiego" - zauważają Birnbaum i Kieffer ${ }^{34}$.

Zbigniew Kwieciński, analizując związek między położeniem szkolnym i społecznym absolwentów szkoły podstawowej a poziomem krytycyzmu wobec mitów szkolnych i świadomości krytycznej wobec rzeczywistych funkcji rozwojowych i społecznych szkoły, pisał: „Krytycyzm wobec mitów i funkcji szkoły jest ujemnie skorelowany z niekorzystnym położeniem rodziny i niekorzystnym przebiegiem kariery szkolnej. W efekcie zachodzi odwrócenie świadomości, inwersja symboliczna: młodzież poddana opresyjnym działaniom szkoły i nie odnosząca w niej sukcesu najbardziej ufnie odnosi się do »obietnicy« oświeceniowej szkoły, natomiast młodzież, która odziedziczyła korzystne położenie społeczne i kulturowe oraz odniosła sukces w szkole najsilniej krytykuje szkołę, odczuwa jej opresję i nudę, odrzuca jej ideologię, sukces przypisuje sobie, a nie pracy nauczycieli”35. Wydaje się, że również w sytuacji uczniów imigrantów występuje ta symboliczna inwersja, odzwierciedlając się w poziomie aspiracji edukacyjnych młodzieży, ich planach zawodowych, wyborach i losach szkolnych nie tylko na pierwszych progach selekcyjnych.

34 Y. Brinbaum, A. Kieffer: D’une génération à l'autre... cyt. wyd., s. 69.

35 Z. Kwieciński: Socjopatologia edukacji. Olecko 1995, Wydawnictwo Uniwersyteckie „Trans Humana”, s. 173. 
Pozostaje więc wciąż wiele pytań dotyczących procesów kształtowania się aspiracji imigrantów. Modele teoretyczne, które traktują przede wszystkim pozycje społeczne jako wektory aspiracji edukacyjnych, nie przynoszą w pełni zadowalających odpowiedzi. Proces transmisji kulturowej ma zastosowanie w niektórych przypadkach. Ma to miejsce, gdy aspiracje rodziców imigrantów są przekazywane dzieciom - a więc stanowiłoby to rodzaj kulturowego dziedzictwa rodzinnego. Również koncepcja habitusu i socjalizacji pierwotnej dobrze nadaje się do interpretowania wysokich aspiracji edukacyjno-zawodowych uczniów pochodzenia azjatyckiego, takich jak Wietnamczycy, Koreańczycy czy Japończycy, jednak nie ułatwia ustalenia przyczyn wysokich aspiracji uczniów imigrantów pochodzących z krajów nieazjatyckich.

Nie wydaje się, aby w ramach jednego modelu (teorii) można było prawomocnie wyjaśnić interesujące zjawisko wysokich aspiracji edukacyjnych uczniów imigrantów, bowiem ich uwarunkowania są wieloczynnikowe, na co wskazują zasygnalizowane interpretacje.

Sądzę, że można by - przy wyjaśnianiu wysokich aspiracji edukacyjno-zawodowych uczniów imigrantów - przyjąć hipotezę nawiązującą do koncepcji społeczeństwa merytokratycznego. Koncepcja ta ma wyjaśniać mechanizmy sprawiedliwego rozdziału nagród za pośrednictwem systemu edukacyjnego ${ }^{36}$. Zgodnie z tą koncepcją system edukacyjny dokonuje alokacji jednostek w strukturze społecznej stosownie do ich zdolności i osiągnięć. Nie likwidując społecznych nierówności, uruchamia mechanizmy stratyfikacyjne, które w optymalny sposób kanalizują ludzi zarówno do niskich, jak i wysokich pozycji społecznych. W ten sposób reprodukcja zawodowych statusów rodziców ze środowisk zmarginalizowanych przez ich dzieci może ulec osłabieniu. To dyplom, a przede wszystkim dyplom uniwersytecki, ma gwarantować młodym ludziom awans społeczny i osiągnięcie życiowego sukcesu. Ta idea społeczeństwa merytokratycznego jest poddawana krytyce przez zwolenników koncepcji społeczeństwa kredencjalnego. Argumentują oni, że osiągnięcie życiowego sukcesu przez młodych ludzi ze środowisk zmarginalizowanych, a (dodać można) tym bardziej ze środowiska imigranckiego, jest znacznie trudniejsze niż dla tych, którzy pochodzą z warstw uprzywile-

36 Z. Melosik: Społeczne funkcje szkolnictwa amerykańskiego. „Edukacja” 1993, nr 3; A. Gromkowska-Melosik, T. Gmerek: Problemy nierówności społecznej w teorii i praktyce edukacyjnej. cyt. wyd., s. 9 i n.; Z. Melosik: Edukacja a stratyfikacja społeczna. W: Z. Kwieciński, B. Śliwerski (red.): Pedagogika. Podręcznik akademicki. Warszawa 2004, PWN. 
jowanych. A zatem współcześnie upowszechnienie edukacji uniwersyteckiej, prowadzące do inflacji dyplomów, nie gwarantuje jednostce uzyskania wysokiej pozycji społecznej i zawodowej, nie zapewnia wertykalnej ruchliwości społecznej. Są też badacze, którzy próbują godzić te stanowiska lub przedstawiają koncepcje alternatywne.

Ta krytyka merytokratyzmu nie unieważnia jednak zasadności przyjęcia hipotezy, że dyskurs zdominowany przez ideologię społeczeństwa merytokratycznego, który towarzyszył ekspansji szkolnictwa po drugiej wojnie światowej, odniósł sukces w środowisku imigranckim. Imigranci (w krajach przyjmujących wysoko rozwiniętych) w większości mieli (i nadal mają) przeświadczenie, że kredencjały edukacyjne (uzyskane dyplomy) umożliwią ich dzieciom sukces życiowy, że edukacja zapewni im lepsze szanse rozwoju niż te, które stały się ich udziałem.

Wprawdzie praktyka pokazuje, że międzypokoleniowa ruchliwość w odniesieniu do imigrantów dokonuje się w bardzo ograniczonym wymiarze (przeszkody: jawna lub ukryta dyskryminacja, obniżenie roli i rangi dyplomów), jednakże rodzice imigranci wciąż zdają się pokładać w edukacji nadzieję na polepszenie kondycji społeczno-ekonomicznej swego potomstwa (wierząc, że z dodatkowej edukacji wynikać będą dodatkowe korzyści społeczne i ekonomiczne, że dzieci skorzystają z otwierających się możliwości i szans, jakie oferuje kraj przyjmujący, że zmiana zależy od motywacji, aspiracji i gotowości do ciężkiej pracy), a młodzież (generalnie) interioryzuje te nadzieje i aspiracje rodzicielskie. Ujawnia się tu wyraźnie funkcja przekazu habitusu via rodzina jako środowiska wychowawczego: oddziałuje na osobowość dziecka (ucznia), wytycza i utrwala określony zestaw wartości, które w wyniku interioryzacji stają się dla dziecka (ucznia) „drogowskazami”, ukierunkowującymi jego aktywność szkolną i kształtowanie planów życiowych.

Można więc mówić o występowaniu tu zjawiska utożsamiania się, identyfikacji, które to pojęcia pozwalają traktować ludzkie działania jako sensowne, racjonalne, dające się wyjaśniać i analizować, na co zwraca się uwagę w teoriach o racjonalnym podejmowaniu decyzji i modelach decyzyjnych (Boudon). Zakłada się w nich, jak pisał I. Białecki, „że jednostka ma jakieś wyobrażenie o swojej sytuacji, jakoś się samookreśla (np. przez swoją grupę odniesienia, rodzinę, czy pochodzenie lub płeć) i w tej sytuacji, jej działania można uznać za sensowne" ${ }^{37}$.

37 I. Białecki: Wybór szkoty a reprodukcja struktury społecznej. Wrocław 1982, „Ossolineum”, s. 16. 
Zbyszko Melosik, prezentując stratyfikacyjną i socjalizacyjną funkcję szkolnictwa amerykańskiego oraz przygotowanie młodych ludzi do adaptacji w społeczeństwie amerykańskim, podkreślał zakodowywanie w świadomości jednostki merytokrytycznej ideologii równości edukacyjnych szans. Nie jest ono tylko specyfiką amerykańską, lecz pewną prawidłowością w społeczeństwach postnowoczesnych zdominowanych przez gospodarkę rynkową, o czym świadczyłyby sygnalizowane postawy i orientacje na „zmianę” imigranckich wspólnot etnicznych w krajach europejskich i pozaeuropejskich.

Autorka jest świadoma, że przedstawione interpretacje specyficznych aspiracji uczniów imigrantów nie wyczerpują i nie wykluczają innych czynników lub zmiennych dla wyjaśnienia zachowań i decyzji edukacyjnych imigrantów.

\section{Bibliografia}

Becker G. S.: Human capital: a theoretical and empirical analysis, with special reference to education. Chicago1964, University of Chicago Press (kilkakrotnie wznawiane).

Białecki I.: Wybór szkoły a reprodukcja struktury społecznej. Wrocław 1982, "Ossolineum”.

Boudon R.: Efekt odwrócenia. Niezamierzone skutki działań społecznych. Warszawa 2008, Oficyna Naukowa.

Boudon R.: Logika działania społecznego. Wstęp do analizy socjologicznej. Kraków 2009, „Nomos”.

Bourdieu P., Passeron J.-C.: Les héritiers: les étudiants et la culture. Paris 1964, Editions de Minuit.

Bourdieu P., Passeron J.-C.: Reprodukcja. Elementy teorii systemu nauczania. Warszawa 2011, PWN.

Bourdieu P.: L'école conservatrice. Les inégalités devant l'école et devant la culture. „Revue française de sociologie” 1966, vol. 2, nr 3.

Brinbaum Y., Cebolla-Boado H.: The school careers of ethnic minority youth in France. „Ethnicities” 2007, nr 7 (3).

Brinbaum Y., Kieffer A.: D’une génération à l’autre: les aspirations éducatives des familles immigrés. Ambitions et pérséverance. „Education et formation" 2005, nr 72.

Chua A.: Bojowa pieśń tygrysicy. Warszawa 2011, Wyd. Prószyński Media. 
Coard B.: Haw the West Indian child is made educationally sub-normal in the British school system. London 1971, New Beacon Books.

Collins R.: The credential society. An historical sociology of education and signification. New York 1979, Academic Press.

Cylkowska-Nowak M.: Społeczne funkcje szkolnictwa w Japonii i Stanach Zjednoczonych (stadium z pedagogiki porównawczej). Poznań - Toruń 2000, „Edytor”.

Gromkowska-Melosik A., Gmerek T.: Problemy nierówności społecznej w teorii i praktyce edukacyjnej, Kraków 2008, Oficyna Wydawnicza „Impuls”.

Gupta Y. P.: The educational and vocational aspirations of Asian immigrant and English school-leavers - a comparative study. „British Journal of Sociology" 1977, nr 28.

Halik T., Nowicka E., Połeć W.: Dziecko wietnamskie w polskiej szkole. Warszawa 2006, Wydawnictwo „Prolog”.

James C.: Getting there and staying there: black's employment experience. W: P. Anisef, P. Axelrod (eds): Transitions: schooling and employment in Canada. Toronto 1993, Thompson.

Janik S.: Aspiracje i plany edukacyjno-zawodowe uczniów cudzoziemskich w aglomeracji warszawskiej. Praca doktorska napisana pod kierunkiem naukowym prof. zw. dr. hab. W. Rabczuka. Warszawa 2012.

Krahn H., Taylor A.: Resilient teenagers: explaining the high educational aspirations of visible minority immigrant youth in Canada. PCERII Working Paper Series 2005 (nr WPO2-05).

Kruczkowska M.: Azjatyckie supermatki. „Gazeta Wyborcza” 2012, nr 4.04.

Kwieciński Z.: Socjopatologia edukacji. Olecko 1995, Wydawnictwo Uniwersyteckie "Trans Humana”.

Li J.: Parental expectations of Chinese immigrants. A folk theory about children's school achievement. "Race, ethnicity and education” 2004, nr 7 (2).

Ma P. W., Yeh Ch. J.: Individual and familial factors influencing the educational and career plans of Chinese immigrant youths. "Career Development Quarterly" 2010, nr 58 (3).

MacLeod J.: Ain't no makin'it: Leveled aspirations in a low-income neighbourhood. Boulder1987, Westview.

Melosik Z.: Edukacja a stratyfikacja społeczna. W: Z. Kwieciński, B. Śliwerski (red.): Pedagogika. Podręcznik akademicki. Warszawa 2004, PWN.

Melosik Z.: Społeczne funkcje szkolnictwa amerykańskiego. „Edukacja” 1993, nr 3. 
Perron J.: Ethnicity and educational aspirations of high school students. W: B. Galaway and J. Hudson (eds): Youth in transition: perspectives on research and policy. Toronto1997, Thompson.

Rabczuk W.: Niepowodzenia szkolne dzieci imigrantów w świetle badań amerykańskich i francuskich. W: T Lewowicki, E. Ogrodzka-Mazur (red.): W poszukiwaniu teorii przydatnych $w$ badaniach międzykulturowych. Cieszyn 2001, UŚ - Filia w Cieszynie.

Rex J., Tomlinson S.: Colonial immigrants in a British city-a class analysis. London 1979, Routlege \& Kegan Paul.

Rutter M. et al.: Children of West Indian immigrants. Rates of behavioral deviance and psychiatric disorder. "Journal of Child Psychology and Psychiatry" 1974, nr 15.

Suárez-Orozco C., Suárez-Orozco M.: Children of immigrants. Cambridge 2001, Harvard University Press.

Tribalat M.: Faire France. Une enquête sur les immigrés et leurs enfants. Paris 1995, La Découverte.

Yu E. S.: Chinese collective orientation and need for achievement. „International Journal of Social Psychiatry" 1980, nr 26 (3).

Zieliński M.: Zostanę prezydentem Polski. „Gazeta Wyborcza. Stołeczna” 2005, nr 8-9.10.

Zirotti J.-P., Akers-Porrini R.: Élèves "français" et "maghrébins". Un rapport different à l'orientation scolaire. „Migration-Formation” 1992, nr 89.

\section{Educational aspirations of immigrant learners}

\section{Summary}

The issues which the author focuses on are educational aspirations of immigrant learners. In reference to foreign and partially the author's own studies, attention is drawn to high educational aspirations of this category of learners - generally, higher than autochthonic learners of the same socio-economic status. What is indicated is the researchers' lack of agreement in explaining the determinants of the specificity of these aspirations. The interpretation models situated within P. Bourdieu and J.-C. Passeron's theory of reproduction, G. S. Becker's concepts of rationality, investment and profitability, or R. Boudon's model of social mobility associated with the perception of school effectiveness, do not provide fully 
satisfactory explanation of the discussed specificity. Therefore, the need is raised of searching for complementary interpretation models of this phenomenon. This results in a suggestion to apply the concept of meritocratic society to achieve this aim.

Key words: immigrant learners, educational aspirations, specificity of aspiration, determinants, interpretation models

Translated by Agata Cienciała 